\title{
Up-regulation of Arl4a gene expression by broccoli aqueous extract is associated with improved spermatogenesis in mouse testes
}

Omid Jazayeri', Setareh Farahmand Araghi ${ }^{1}$, Tahereh A. Aghajanzadeh ${ }^{2}$, Fereshteh Mir

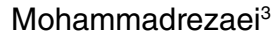

${ }^{1}$ Department of Molecular and Cell Biology, Faculty of Basic Science, University of Mazandaran, Babolsar, Iran

${ }^{2}$ Department of Plant Sciences, Faculty of Basic Science, University of Mazandaran, Babolsar, Iran

${ }^{3}$ Department of Animal Sciences, Faculty of Basic Science, University of Mazandaran, Babolsar, Iran

Introduction: Broccoli (Brassica oleracea) is well known for its properties as an anticancer, antioxidant, and scavenger of free radicals. However, its benefits in enhancing spermatogenesis have not been well established.

Objective: To study broccoli aqueous extract effects on sperm factors and the expression of genes Catsper1, Catsper2, Arl4a, Sox5, and Sox9 in sperm factors in mice.

Material and methods: Male mice were divided randomly into six groups: (1) Control; (2) cadmium ( $3 \mathrm{mg} / \mathrm{kg}$ of mouse body weight); (3) orally treated with $200 \mu \mathrm{l}$ broccoli aqueous extract $\left(1 \mathrm{~g} \mathrm{ml}^{-1}\right)$; (4) orally treated with $400 \mu \mathrm{l}$ of broccoli aqueous extract; (5) orally treated with 200 broccoli aqueous extract plus cadmium, and (6) orally treated with $400 \mu \mathrm{l}$ of broccoli aqueous extract plus cadmium. We analyzed the sperms factors and Catsper1, Catsper2, Arl4a, Sox5, and Sox9 gene expression.

Results: An obvious improvement in sperm count and a slight enhancement in sperm motility were observed in mice treated with broccoli extract alone or with cadmium. Sperm viability was reduced by broccoli extract except for the $200 \mu \mathrm{l}$ dose with cadmium, which significantly increased it. Interestingly, Arl4a gene expression increased in the $400 \mu \mathrm{l}$ broccolitreated group. Likewise, the Arl4a mRNA level in mice treated with cadmium and $200 \mu \mathrm{l}$ of broccoli extract was higher than in the cadmium-treated mice. Furthermore, broccoli extract enhanced the mRNA level of Catsper2 and Sox5 genes in mice treated with $200 \mu \mathrm{l}$ and 400 $\mu \mathrm{l}$ broccoli extract plus cadmium compared with the group treated solely with cadmium. Conclusion: The higher sperm count in broccoli-treated mice opens the way for the development of pharmaceutical products for infertile men.

Received: $21 / 01 / 2021$

Published: $27 / 07 / 2021$

Citation:

Jazayeri O, Farahmand Araghi S, Aghajanzadeh TA, Mir Moammadrezaei F. Up-regulation of Arl4a gene expression by broccoli aqueous extract is associated with improved spermatogenesis in mouse testes. Biomédica. 2021:41:706-20.

https://doi.org/10.7705/biomedica.5962

Corresponding author:

Omid Jazayeri, Department of Molecular and Cell Biology, Faculty of Sciences, University of Mazandaran, Babolsar, Iran

Mobile: (98) (11) 3530 2457; fax: (98) (113) 5302450

o.jazayeri@umz.ac.ir

\section{Author contributions:}

Tahereh Aghajanzadeh and Omid Jazayeri were responsible for the concept, the design and performance of experiments, the interpretation of results and the supervision of the study.

Setareh Farhmand Araghi performed the experiments in the laboratory and helped in the writing of the manuscript.

Fereshteh Mir Mohammadrezaei helped with animal experiments and the performance and interpretation of the sperm factors results.

Omid Jazayeri wrote the manuscript.

Funding:

The project was supported by a grant from the University of Mazandaran.

Conflicts of interest:

The authors declared no conflicts of interest.
Keywords: Brassica; spermatogenesis; gene expression; mice; cadmium.

La regulación positiva de la expresión del gen Arl4a por acción del extracto acuoso de brócoli se asocia con una mejor espermatogénesis en testículos de ratón.

Introducción. El brócoli (Brassica oleracea) se conoce por sus propiedades como anticancerígeno, antioxidante y eliminador de radicales libres. Sin embargo, sus beneficios en la espermatogénesis aún no se han determinado suficientemente.

Objetivo. Estudiar los efectos del extracto acuoso de brócoli sobre los factores espermáticos y la expresión de los genes Catsper1, Catsper2, Arl4a, Sox5 y Sox9 en ratones.

Materiales y métodos. Los ratones machos se dividieron aleatoriamente en seis grupos: 1) control; 2) tratados con cadmio, $3 \mathrm{mg} / \mathrm{kg}$ de peso corporal; 3) tratados con $200 \mu \mathrm{l} \mathrm{de}$ extracto acuoso de brócoli $\left.\left(1 \mathrm{~g} \mathrm{ml}^{-1}\right) ; 4\right)$ tratados con $400 \mu \mathrm{l}$ de extracto acuoso de brócoli; 5) tratados con $200 \mu \mathrm{l}$ de extracto acuoso de brócoli más cadmio, y 6) tratados con $400 \mu \mathrm{l}$ de extracto acuoso de brócoli más cadmio. El extracto acuoso de brócoli se administró por vía oral. Se analizaron los factores espermáticos y la expresión de los genes Catsper1, Catsper2, Arl4a, Sox5 y Sox9.

Resultados. Se observó una mejoría obvia en el recuento y una ligera mejoría en la motilidad de los espermatozoides, en ratones tratados con extracto de brócoli solo o con cadmio. La viabilidad de los espermatozoides se redujo con el extracto de brócoli, excepto con la dosis de $200 \mu$ más cadmio, la cual la aumentó significativamente. Curiosamente, la expresión del gen Arl4a aumentó en el grupo tratado con $400 \mu \mathrm{l}$ del extracto. Asimismo, el ARNm del Arl4a en ratones tratados con cadmio y $200 \mu \mathrm{l}$ del extracto, fue más abundante que en los ratones tratados solo con cadmio. Además, el extracto de brócoli aumentó la cantidad de ARNm de los genes Catsper2 y Sox 5 en ratones tratados con 200 y $400 \mu \mathrm{l}$ de extracto de brócoli más cadmio, en comparación con el grupo tratado únicamente con cadmio.

Conclusión. El mayor número de espermatozoides en ratones tratados con brócoli abre el camino al desarrollo de productos farmacéuticos para hombres infértiles.

Palabras clave: Brassica; espermatogénesis; expression génica; ratones; cadmio. 
Infertility is defined by the failure to achieve a clinical pregnancy after one year or more of regular unprotected sexual intercourse. Approximately $40-50 \%$ of all infertility cases are due to male factors (1). While reproductive technologies can counter male infertility, genetic defects may still be passed to the male's offspring (2).

Medicinal plants are used for the development of new drugs, as well as for health care. For example, Trigonellae Semen, derived from Trigonella foenum-graecum L., is commonly used as a medicinal herb for the treatment of infertility in Korean medicine (2). Panax ginseng is a traditional medicinal plant for male infertility and rats treated with ginseng had had a significant increase in sperm count and sperm motility $(3,4)$. Aspalathus linearis and Camellia sinensis have also a forceful positive impact on sperm factors (5). Decursin, extracted from Angelica gigas, has also shown a positive effect on sperm counts and motility in cryptorchidism-induced infertile rats (6). The protective effect of Crocus sativus L. on cadmium (Cd) toxicity in rat spermatogenesis has been reported as well (7). Besides, recent evidence suggests that the $\mathrm{Ca}^{2+}$ levels of mice sperm cells treated with $P$. ginseng extract increased significantly compared with the normal group inducing the expression of CatSper genes (involved in sperm motility and fertility) $(8,9)$.

There is a growing body of literature on the therapeutic effects of cruciferous plants like broccoli largely attributed to their high content of glucosinolates. Broccoli is well known worldwide for its anti-cancer effects (10) and its antioxidant properties, which make it the finest natural active substance for scavenging free radicals $(11,12)$, as an antigenotoxic agent (13), a reducer of fasting blood glucose in type 2 diabetes patients (14), a protection agent of the cardiovascular (15) and central nervous systems, against diabetic nephropathy and neuropathy (16), beneficial in the restoration of skin integrity (17), against Helicobacter pylori infection (18), and for the improvement of social interaction in patients with autism (19).

Heavy metal pollutants such as cadmium and lead are considered sources of significant environmental damage as they do not have any biological functions and can be extremely toxic even at low concentrations (20). The toxic effect of heavy metals on living organisms' health are expressed in diseases and conditions like cancer, infertility, nephritis, hair loss, brain damage, cardiovascular disease, low blood pressure, and paralysis. However, kidney and lung damage, fragile bones, and calcium deregulation in biological systems have been determined as specific toxicological effects of cadmium (21).

The effect of broccoli on spermatogenesis and related gene expression in mouse testes has yet to be determined. The genetic bases and molecular mechanisms underlying spermatogenesis and its molecular regulation are not fully understood yet. In this context, in the present study, we analyzed the impact of broccoli extract on sperm count and the expression of Arl4a gene (involved in spermatogenesis) (22), of Catsper1 and Catsper2 genes (involved in sperm motility) (23), as well as that of Sox5 and Sox9 genes (transcription factors involved in the Sertoli cells and sex development) (24).

\section{Materials and methods}

\section{Experimental animals}

The study was approved by the Ethics Committee at the University of Mazandaran, Iran (IR.UMZ.REC.1399.002). We purchased NMRI male mice 
(5-6 weeks old between 25-30 g of weight) from the Pasteur Institute (Tehran, Iran), which were kept for one week in polycarbonate cages for adaptation to their new environment until reaching the desired conditions. They were kept under standard conditions ( $12 \mathrm{~h}$ light/dark cycle at $24 \pm 2^{\circ} \mathrm{C}$ ) with free access to drinking water and standard pellets. Once every two days, the cages were cleaned, the remaining food was collected, and fresh food was provided. Finally, they were anesthetized intraperitoneally with ketamine hydrochloride $\left(100 \mathrm{mg} \mathrm{kg}^{-1}\right)$ and xylazine $\left(5 \mathrm{mg} \mathrm{kg}^{-1}\right)$.

\section{Preparation of the broccoli aqueous extract}

Two-month broccoli was collected from a local greenhouse, immediately frozen and transferred to the plant physiology laboratory. Broccoli flowers were grinned in liquid nitrogen to a fine powder, dissolved in boiling water, and boiled for 3 minutes $\left(1 \mathrm{~g} \mathrm{ml}^{-1}\right)$. Then, the suspension was filtered through one layer of filter paper and the extraction was centrifuged at $10,000 \mathrm{~g}$ for 10 minutes at $4^{\circ} \mathrm{C}$ and stored at $-20^{\circ} \mathrm{C}$ for further experiments (25).

\section{Experimental design}

Thirty-six NMRI male mice were divided randomly into the following six groups, with six animals per group: 1) control; 2) cadmium, $3 \mathrm{mg} / \mathrm{kg}$ of mouse body weight; 3 ) orally treated mice with 200 broccoli aqueous extract ( $1 \mathrm{~g}$ $\mathrm{ml}^{-1}$ ); 4) orally treated with $400 \mu \mathrm{l}$ of broccoli aqueous extract; 5) orally treated with 200 broccoli aqueous extract plus cadmium, and 6) orally treated with $400 \mu \mathrm{l}$ of broccoli aqueous extract plus cadmium. The mice in the control group only received distilled water. In the cadmium group, mice were injected intraperitoneally only with cadmium chloride ( $3 \mathrm{mg} / \mathrm{kg}$ of mouse body weight). Four of the groups were orally administered 200 and $400 \mu \mathrm{l}$ of the extract (1 $\mathrm{g} \mathrm{ml}^{-1} / 60 \mathrm{~g}$ of mouse body weight) with and without intraperitoneally injection of cadmium chloride. The extract was administered every day for 48 days and cadmium on the last day of the treatment. On the 49th day of the experiment, all animals were sacrificed and samples were collected. The sperm was rapidly detached from the epididymis and used to determine the parameters. Mice testis were separated, immediately frozen in liquid nitrogen, and stored at $-80^{\circ} \mathrm{C}$ for subsequent RNA extraction.

\section{Evaluation of cauda epididymal sperm count and motility}

We used the seminal plasma aspirated from the caudal part of the mice epididymis for the semen analysis. The epididymis was put in a solution containing $1 \mathrm{ml}$ of PBS buffer ( $\mathrm{pH}=7$ ) and then cut into small pieces. We incubated the tissue homogenate at $37^{\circ} \mathrm{C}$ for 10 minutes to release the sperm in the solution. We placed $10 \mu \mathrm{l}$ of the sperm on a clean slide coverslip for sperm count and motility evaluation (26). Total sperm counts were determined with a hemocytometer under a light microscope at 200X magnification. Spermatozoa were collected with a micropipette and placed on a slide for motility estimation and classification into motile and non-motile sperms. Motility was expressed as the percentage of sperm showing movement (fast forward, slow movements, and movement in place); data were expressed as percentages (26).

\section{Sperm viability}

Viability was assessed by eosin-nigrosin solution (26): A $10 \mu \mathrm{l}$ sample of the sperm suspension was placed on a glass slide, mixed with $10 \mu \mathrm{l} \mathrm{eosin}$, and after drying at laboratory temperature observed under a light microscope $(400 X)$. With this procedure, the head of the dead spermatozoa absorbs 
eosin and becomes red, but live spermatozoa appear colorless as the plasma membrane remains intact. Live spermatozoa were counted in five fields of vision at random and their percentage was recorded.

\section{Semi-quantitative RT-PCR}

RNA extraction and cDNA synthesis. Total RNA was extracted from the mice testis using RNX plus (EX6101) solution following the manufacturer's protocol (SINACLON, Iran). The RNA pellet was dissolved in RNase-free water (DEPC treated water). Total RNA was then treated with DNAasel (SINACLON, Iran) to destroy possible genomic DNA contamination followed by heat treatment $\left(65^{\circ} \mathrm{C}\right.$ for 10 minutes) to inactivate the enzyme and then stored at $-80^{\circ} \mathrm{C}$ for future cDNA synthesis. We checked the purity and integrity of the total RNA extracted at $260 / 280 \mathrm{~nm}$ ratio using a Thermo Scientific NanoDrop spectrophotometer and visualized it on $1 \%$ agarose gel. We used a commercial cDNA synthesis kit (2-steps RT-PCR kit, Vivantis, Malaysia) following the manufacturer's instructions. Briefly, $1 \mu \mathrm{g}$ of total RNA, $0.5 \mu \mathrm{l} \mathrm{M-MuLV}$ Reverse Transcriptase $(200 \mathrm{U} / \mu \mathrm{l}), 2 \mu \mathrm{l}$ of 10X Buffer M-MuLV, $1 \mu \mathrm{l}$ Oligo $\mathrm{d}(\mathrm{T}) 18(40 \mu \mathrm{M}), 1 \mu \mathrm{l}$ of $10 \mathrm{mM}$ dNTPs were added to a $0.2 \mathrm{ml}$ microcentrifuge tube. The reaction mixture was adjusted to the final $20 \mu \mathrm{l}$ volume with nuclease-free water.

\section{Polymerase Chain Reaction (PCR)}

Primer sequences, GeneBank ID, and amplification product sizes are summarized in table 1. Primers were synthesized (Metabion, Germany) and samples were normalized with the $\beta$ actin gene as a reference gene for its constitutive expression. Synthesized cDNA was amplified by PCR reaction performed by using 2x PCRBIO Taq Mix Red in a reaction volume of 12.5 $\mu \mathrm{l}$ containing $6.25 \mu \mathrm{l} 2 \mathrm{x}$ PCRBIO Taq Mix Red, $0.5 \mu \mathrm{l}$ of each of the forward and reverse primers (10 pM), $1.5 \mu \mathrm{l} \mathrm{CDNA}$, and $3.75 \mu \mathrm{l} \mathrm{H}_{2} \mathrm{O}$. PCR conditions for Catsper1, Catsper2 and Sox 9 were: $94^{\circ} \mathrm{C}$ for 2 minutes followed by 36 cycles $\left(94^{\circ} \mathrm{C}\right.$ for $30 \mathrm{~s}, 57^{\circ} \mathrm{C}$ for $30 \mathrm{~s}$, and $72^{\circ} \mathrm{C}$ for $1 \mathrm{~min}$ as an extension), and a final extension at $72^{\circ} \mathrm{C}$ for $10 \mathrm{~min}$. For Sox5, the conditions were: $94^{\circ} \mathrm{C}$ for 2 minutes followed by 32 cycles $\left(94^{\circ} \mathrm{C}\right.$ for $30 \mathrm{~s}, 60^{\circ} \mathrm{C}$ for $30 \mathrm{~s}$, and $72^{\circ} \mathrm{C}$ for 1 minute as an extension), and a final extension at $72^{\circ} \mathrm{C}$ for 10 minutes. For Arl $4 a$ and $\beta$ actin, the conditions were: $94^{\circ} \mathrm{C}$ for 2 minutes followed by 30 cycles $\left(94^{\circ} \mathrm{C}\right.$ for $30 \mathrm{~s}, 57^{\circ} \mathrm{C}$ for $30 \mathrm{~s}$, and $72^{\circ} \mathrm{C}$ for 1 minute as an extension) and a final extension at $72^{\circ} \mathrm{C}$ for 10 minutes.

Table 1. Sequence of the designed primers used for RT-PCR

\begin{tabular}{|c|c|c|c|c|c|c|}
\hline Gene & Function & $\begin{array}{l}\text { Accession } \\
\text { number }\end{array}$ & Primer sequences & Product size & $\begin{array}{l}\text { Optimized } \\
\text { cycle number* }\end{array}$ & Reference \\
\hline CatSper1 & Sperm motility & NM_139301.3 & $\begin{array}{l}\text { Forward: 5'-'TCGGAGAACCACAGAGAAGAG-3' } \\
\text { Reverse: 5'-CACACACCGGGAATATCTTC-3' }\end{array}$ & $566 \mathrm{bp}$ & 36 & (27) \\
\hline CatSper2 & Sperm motility & NM_153075.3 & $\begin{array}{l}\text { Forward: 5'-TGGCCACAGAGCAGTATTTG-3' } \\
\text { Reverse: 5'-TGTCAGGCTGTTGCTTTGTC-3' }\end{array}$ & $513 \mathrm{bp}$ & 36 & (27) \\
\hline Arl4a & Spermatogenesis & NM_007487.3 & $\begin{array}{l}\text { Forward: 5'- CAGGCTGCAGTTCAACGAAT-3' } \\
\text { Reverse: 5'- AATGCCAAGGAGTCGATGAG-3' }\end{array}$ & $377 \mathrm{bp}$ & 30 & Current study \\
\hline Sox5 & Transcription factor & NM_001113559.2 & $\begin{array}{l}\text { Forward: 5'- CCCCACATAAAGCGTCCAATG-3' } \\
\text { Reverse: 5'- TCTCCAGGTGCTGTTTGCTGAG-3' }\end{array}$ & $196 \mathrm{bp}$ & 32 & (28) \\
\hline Sox9 & Transcription factor & NM_011448.4 & $\begin{array}{l}\text { Forward: 5'-GAAGCTGGCAGACCAGTACC-3' } \\
\text { Reverse: 5'- CTGCTCAGTTCACCGATGTC-3' }\end{array}$ & $479 \mathrm{bp}$ & 36 & (29) \\
\hline$\beta$ actin & Reference gene & NM_007393.1 & $\begin{array}{l}\text { Forward: 5'-'GGGAAATCGTGCGTGACAT - 3' } \\
\text { Reverse: 5'- TCAGGAGGAGCAATGATCTTG -3' }\end{array}$ & $385 \mathrm{bp}$ & 30 & (27) \\
\hline
\end{tabular}

The number of PCR cycles was determined to obtain a detectable signal without reaching saturation. 
We determined the number of PCR cycles for each gene to obtain a detectable signal without reaching saturation. For the electrophoresis of amplified products, we used $1 \%$ agarose gel and the amplified cDNA fragment was visualized and photographed under UV light. The band intensities were semi-quantitatively analyzed using the E-capt software (Vilber Lourmat, France) and normalized against that of $\beta$ actin. The resulting data were expressed as means and standard deviation (SD) of at least three PCR replicates.

\section{GeneMANIA in silico analysis to study protein-protein interaction}

We utilized a large set of protein-protein interaction databases within the GeneMANIA package (30) to build a protein-protein interaction network. This package comprises 244 databases/articles that collectively utilize experimentally proved physical protein-protein interactions in humans. The Arl4a gene was used as input for the GeneMANIA algorithm. Although we used "mice" in the study, we selected "Homo sapiens" as the organism in the GeneMANIA input setting because protein-protein interaction in "human" is more complete than in "mouse" and, thus, it provided a more comprehensive insight into Arl4a biological functions.

\section{Statistical analysis}

All data were analyzed using the Prism software, one-way ANOVA, and Tukey post-test at a significance level of $p \leq 0.05$.

\section{Results}

\section{Impact of the broccoli extract on the body and testis weight with and without Cd-toxicity}

No significant difference was evident between groups regarding body and testis weight (table 2).

\section{Impact of the broccoli extract on sperm parameters with and without $\mathrm{Cd}$ - toxicity}

Figure 1 displays sperm microscopic images in NMRI mice treated with cadmium and the broccoli extract while figure 2 shows the experimental data on sperm parameters: we observed a positive significant impact of the extract on the sperm count in a dose-dependent manner (figure 2A). The sperm count in the $400 \mu \mathrm{l}$ extract-treated group was 1.5, i.e., two-fold higher than in the $200 \mu \mathrm{l}$ extract-treated and the control groups (figure 1, A, C and E). Additionally, we found a clear benefit of the extract in the prevention of $\mathrm{Cd}$ toxicity in the sperm count. Likewise, the sperm count significantly increased in the extract (almost 2.5 fold) and CD-treated ( 2.7 fold) groups (200 and 400 $\mu \mathrm{l})$ compared to the mice treated only with $\mathrm{Cd}$ (figure 1B, D, F).

Table 2. Body and testis weight in NMRI male mice treated with 200 and $400 \mu \mathrm{l}$ of broccoli extract (BE) of $\left(1 \mathrm{~g} \mathrm{ml}^{-1}\right)$ with and without $\mathrm{Cd}\left(1 \mathrm{mg} \mathrm{kg}^{-1}\right.$ of mouse weight). Data represent the mean of six mice in each group $( \pm S D)$. The different letters indicate a significant difference among groups ( $p \leq 0.05$; Oneway ANOVA; Tukey's HSD all-pairwise comparisons as a post-hoc test).

\begin{tabular}{lcccccc}
\hline Sample & Control & \multirow{2}{*}{ Cd } & $\begin{array}{c}\text { BE } \\
(\mathbf{2 0 0} \boldsymbol{\mu l})\end{array}$ & $\begin{array}{c}\text { Cd+ BE } \\
(\mathbf{2 0 0} \boldsymbol{\mu l})\end{array}$ & $\begin{array}{c}\text { BE } \\
(\mathbf{4 0 0} \boldsymbol{\mu l})\end{array}$ & $\begin{array}{c}\text { Cd+ BE } \\
(\mathbf{4 0 0} \boldsymbol{\mu l})\end{array}$ \\
\hline Body weight $(\mathrm{g})$ & $47.7 \pm 3.9 \mathrm{a}$ & $39.7 \pm 5.2 \mathrm{a}$ & $38.7 \pm 4.8 \mathrm{a}$ & $44.8 \pm 5.7 \mathrm{a}$ & $40.9 \pm 1.5 \mathrm{a}$ & $45.2 \pm 5 \mathrm{a}$ \\
Testis weight $(\mathrm{g})$ & $0.17 \pm 0.03 \mathrm{a}$ & $0.16 \pm 0.04 \mathrm{a}$ & $0.13 \pm 0.01 \mathrm{a}$ & $0.15 \pm 0.03 \mathrm{a}$ & $0.14 \pm 0.02 \mathrm{a}$ & $0.16 \pm 0.02 \mathrm{a}$ \\
\hline
\end{tabular}




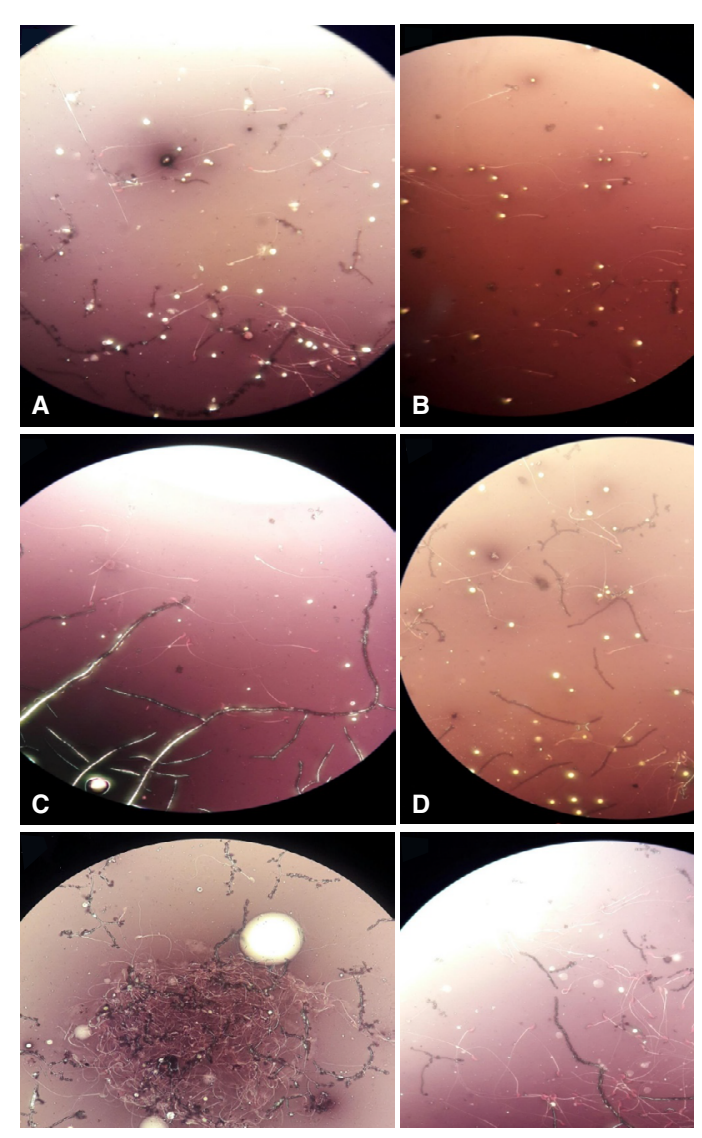

Figure 1. Microscopic images of sperm in NMRI mice treated with $\mathrm{Cd}$ and $\mathrm{BE}$.

A: Control; B: Cd; C: $200 \mu \mathrm{l}$ of BE $(1 \mathrm{~g}$ $\mathrm{ml}-1)$; $\mathrm{D}: 200 \mu \mathrm{l}$ of $\mathrm{BE}(1 \mathrm{~g} \mathrm{ml}-1)$ plus $\mathrm{Cd}$ (3 mg kg-1 of mouse body weight); $\mathrm{E}$ : $400 \mu \mathrm{l}$ of BE $(1 \mathrm{~g} \mathrm{ml}-1) ; \mathrm{F}: 400 \mu \mathrm{l}$ of BE (3 $\mathrm{g} \mathrm{ml}-1)$ plus $\mathrm{Cd}(1 \mathrm{mg} \mathrm{kg}-1) .4 \mathrm{X}$

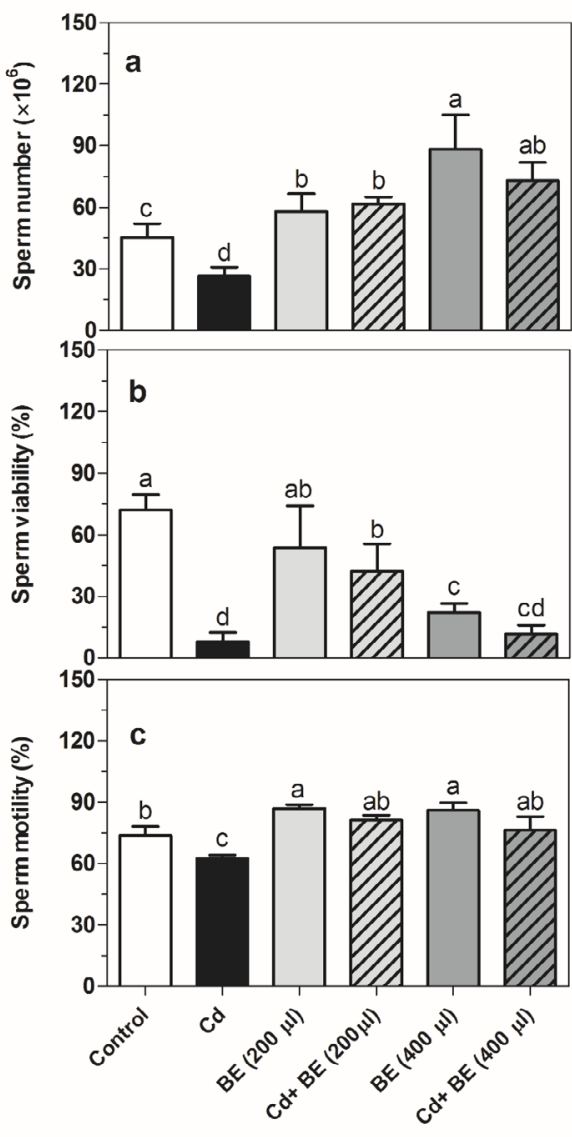

Figure 2. Sperm count (a), sperm viability (b), and sperm motility (c) in NMRI male mice treated with 200 and $400 \mu \mathrm{l}$ of BE $(1 \mathrm{~g} \mathrm{ml}-1)$ with and without $\mathrm{Cd}(1 \mathrm{mg} \mathrm{kg}-1$ of mouse weight). Data represent the mean of six mice in each group $( \pm S D)$. Different letters indicate significant differences among groups $(p \leq 0.05$; Oneway ANOVA; Tukey's HSD all-pairwise comparisons as a post-hoc test). 
Figure 3. Relative gene expression determined by semi-quantitative RT-PCR. The expression of genes corresponds to the ratio of the target gene divided by the reference gene ( $\beta$ actin).

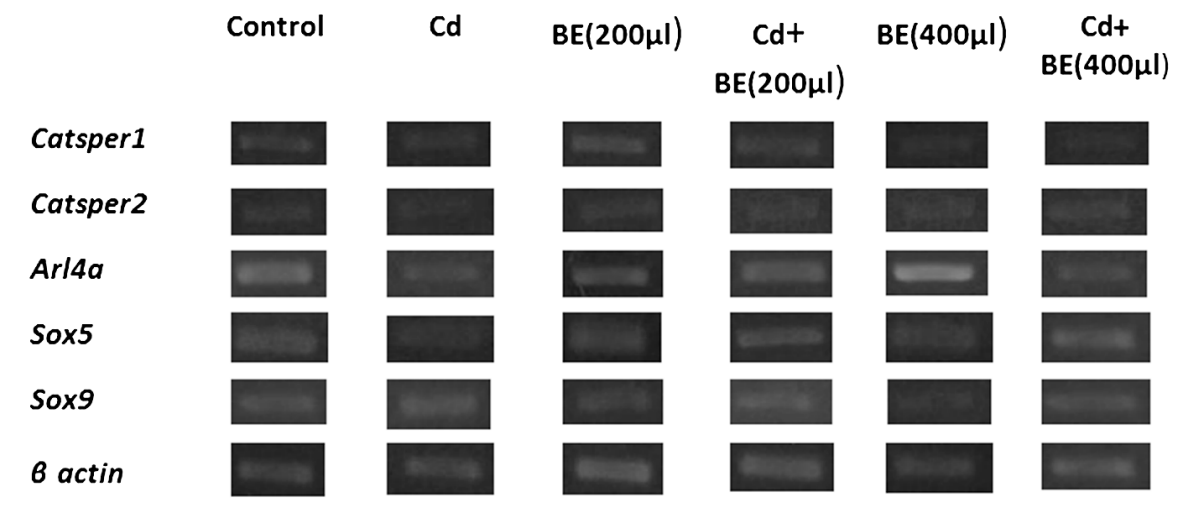

Furthermore, sperm viability was clearly reduced in Cd-treated mice compared with the control group (figure $1 \mathrm{~A}, \mathrm{~B}$; figure $2 \mathrm{~B}$ ). When Cd-treated mice were administered 200 and $400 \mu \mathrm{l}(1 \mathrm{~g} / \mathrm{ml})$ broccoli extract, the sperm viability increased 5.3 and 1.5 fold, respectively (figure $2 \mathrm{~B}$ ).

However, sperm viability hardly changed in mice treated with $200 \mu \mathrm{l}$ extract and acutely decreased in mice treated with $400 \mu$ l extract (figure 2B). Additionally, sperm motility significantly decreased in Cd-treated mice (figure $2 \mathrm{C}$ ), but their treatment with both 200 and $400 \mu \mathrm{l}$ extract led to an increase in sperm motility. Likewise, the mice treated with both extract doses exhibited higher sperm motility than those in the control group.

\section{Impact of the broccoli extract on Catsper1, Catsper2, and Arl4a gene expression with and without Cd-toxicity}

Figure 3 shows the relative gene expression by semi-quantitative RT-PCR while in figure 4 no significant difference in the Catsper 1 gene expression among groups is evident.

Catsper2 gene expression in Cd-treated mice was significantly lower than in the other groups (Figure 4). However, there was no significant difference among extract-treated groups with and without Cd-toxicity and a closer look at the graph indicated that the Catsper2 gene expression in the groups treated with 200 and $400 \mu$ l extract plus Cd was significantly higher than in the mice treated only with $\mathrm{Cd}$ (figure 4).

The Arl4a gene mRNA level was up-regulated (1.8 fold) in the group treated with $400 \mu$ l extract (figure 4 ) while its expression was clearly down-regulated in the group treated only with $\mathrm{Cd}$ but higher in the two groups treated with 200 and $400 \mu \mathrm{l}$ extract plus $\mathrm{Cd}$ than in the mice treated only with Cd (figure 4).

\section{Impact of the broccoli extract on the gene expression of transcription factors SOX5 and SOX9 with and without Cd-toxicity}

Figure 5 provides the experimental data on the gene expression of Sox 5 and Sox9 transcription factors. Following the intraperitoneal administration of $\mathrm{Cd}$, we detected a significant decrease in the Sox5 gene expression. However, no significant differences were found in Sox5 gene expression between extracttreated mice (200 and $400 \mu \mathrm{l}$ ) and the control group while it was significantly up-regulated in the extract plus Cd-treated mice compared with those treated only with $\mathrm{Cd}$. Furthermore, Sox9 gene expression appeared to be unaffected 
by $\mathrm{Cd}$. Likewise, none of the extract-treated mice groups, both with and without Cd, showed significant differences in the Sox9 mRNA level (figure 5).
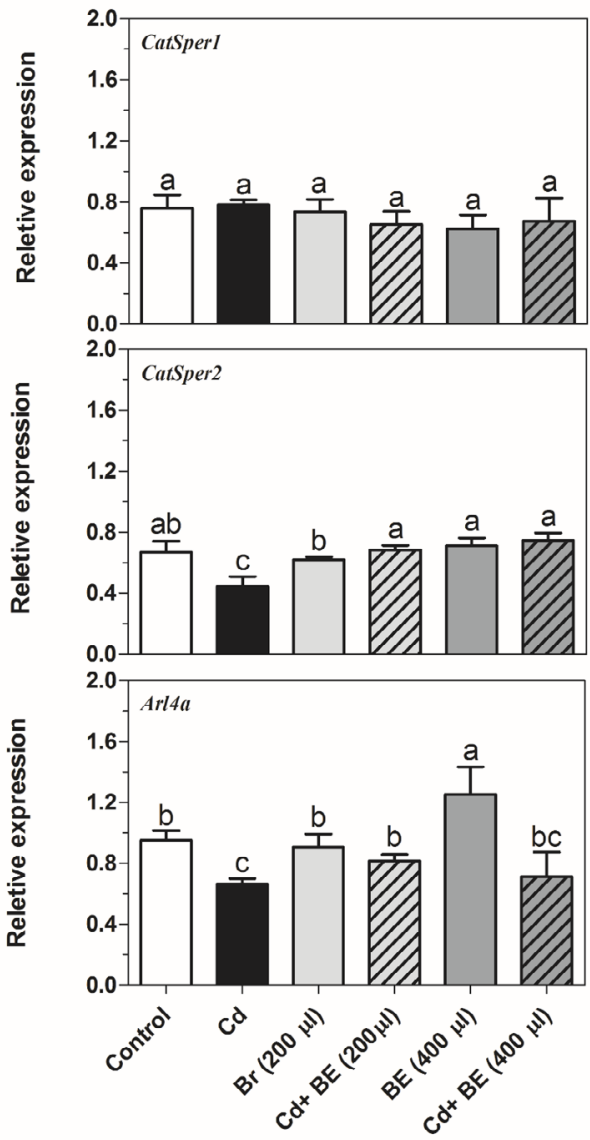

Figure 4. Transcript levels of Catsper1 and Catsper2 (genes involved in sperm motility) as well as Arl4a (gene involved in sperm count) in NMRI male mice. For experimental details, see legend in Figure 1. Relative gene expression was determined by RT-PCR compared to $\beta$ actin as reference gene. Data represent the mean of three mice in each group $( \pm S D)$. Different letters indicate significant differences among groups ( $p \leq 0.05$; Oneway ANOVA; Tukey's HSD all-pairwise comparisons as a post-hoc test).

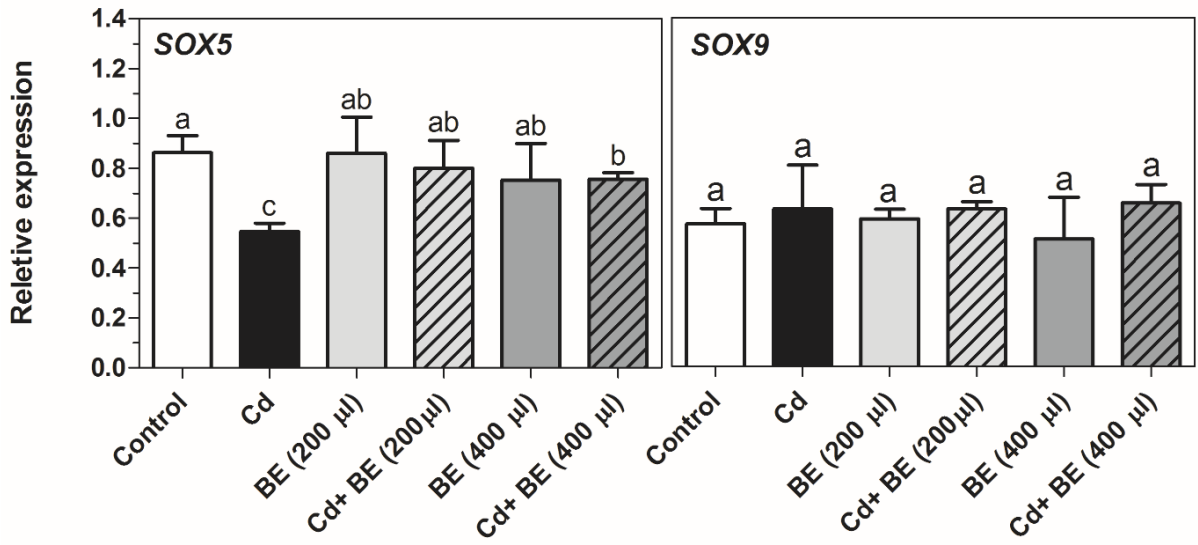

Figure 5. Transcript levels of Sox5 and Sox9 (transcription factors involved in sperm motility) in NMRI male mice. For experimental details, see legend in Figure 1. Relative gene expression was determined by RT-PCR compared to $\beta$ actin as reference gene. Data represent the mean of three mice in each group $( \pm S D)$. Different letters indicate significant differences among groups $(p \leq$ 0.05; Oneway ANOVA; Tukey's HSD all-pairwise comparisons as a post-hoc test). 


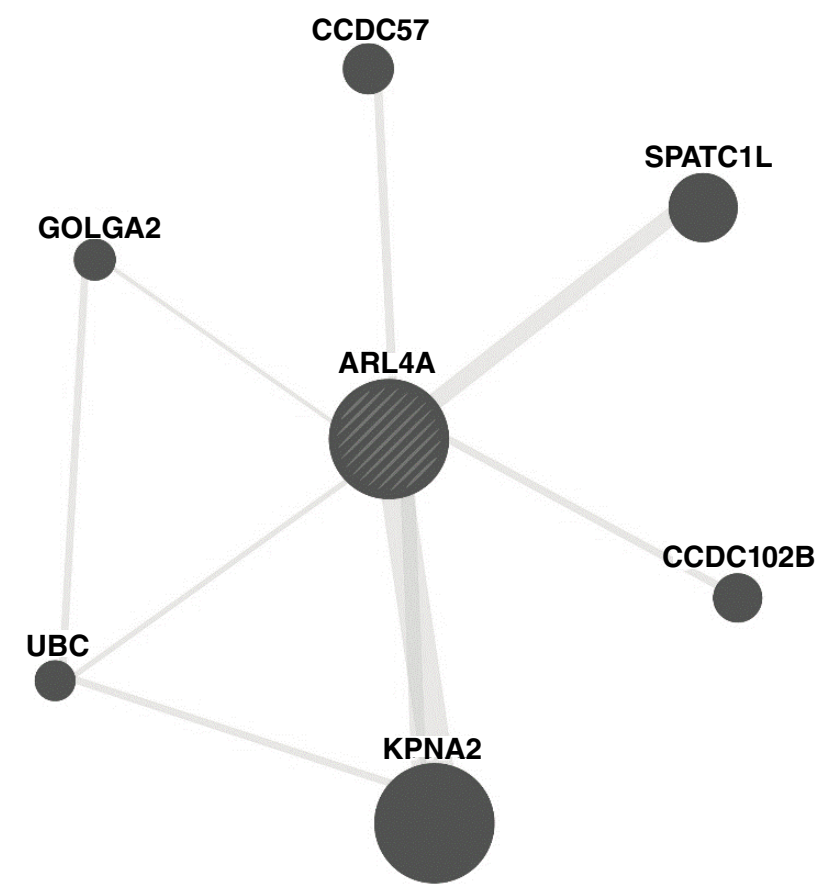

Figure 6. Protein-protein interaction between human ARL4A protein and six other proteins based on the GeneMANIA algorithm

\section{Discussion}

We found few publications on the association between spermatogenesis and broccoli extract $(31,32)$. In such context, we conducted the present study to determine the effect of this extract on the sperm factors and the expression of some genes whose relation to spermatogenesis has already been reported.

The most obvious and interesting finding (figure 2A) was the significant dose-dependent increase in sperm count among extract-treated groups even in the presence of $\mathrm{Cd}$. Surprisingly enough the Arl4a gene expression also showed a similar increase in sperm count in extract-treated groups with and without Cd. ARL4 is a 22-kDa GTP-binding protein abundant in testes of pubertal and adult rodents. In mouse Arl4-null mutants $\left(A r / 4^{--}\right)$the inactivation of the Arl4 gene caused a significant reduction of testis weight and sperm count (30\% and $60 \%$, respectively) (22) and, in general, the association between testis weight and the Arl4a gene has been reported in the literature (33).

Genome-wide mapping in house mice revealed a significant association between SNPs located in the Arl4a gene and relative testis weight. However, no significant difference between body and testis weight among the six groups in our study was found. Similarly, Zhou, et al. did not find significant effects on body and testis weight in mice treated with broccoli seed extract $(0.3,1$, and $3 \mathrm{~g} / \mathrm{kg}$ body weight/day) for 30 days (34) and the broccoli seed extract $L D_{50}$ in rats was $>10 \mathrm{~g} / \mathrm{kg}$ of body weight/day.

Although the role of the Arl4a gene in mouse spermatogenesis was reported in 2002 (22), very little is currently known about its biological functions and spermatogenesis-related mechanisms. In this sense, we conducted an in silico analysis to find further evidence regarding its role in spermatogenesis and its binding proteins using the GeneMANIA algorithm. As shown in figure 6, Arl4a was bound to Spatc1l through the protein-protein 
interaction. Previously, it had been shown that Spatc1l maintains the integrity of the sperm head-tail junction and that Spatc1l knockout mice developed male sterility owing to the separation of sperm heads from tails (35). The Kpna2 gene also presented protein-protein interaction with Arl4a and it has been reported that it is a key mediator of nucleocytoplasmic transport in the embryonic testis. Kpna2 mRNA was identified in pachytene spermatocytes and round spermatids (36) and Kpna2 amount markedly increased in both cells (37). Golga2, another protein physically binding to Arl4a, also plays a role in spermatogenesis. Han, et al. showed that the inactivation of Golga2 caused male infertility in a mouse model. In Golga2 ${ }^{-/-}$mice, acrosome and round sperm heads, characteristic features of human globozoospermia, were absent (38) and the cytoskeleton was disorganized in testes.

During spermatogenesis, the ubiquitin-proteasome pathway (UPP) plays a key role in facilitating the formation of condensed sperm and, therefore, deficient UPP blocks spermatogenesis. Ubiquitination occurs in different cell types during spermatogenesis, especially in spermatocytes differentiating into round and elongated spermatids and, even, in mature sperm in the epididymis (39). As shown in figure 4, ubiquitin C (UBC), one of the ubiquitination enzymes, can also physically bind to Arl4a.

Some studies have focused on the association between CCDC102B (coiled-coil domain containing protein 102b) and spermatogenesis. This protein is active in the assembly of the centrosome linker to maintain centrosome cohesion as it contributes to holding the duplicated centrosomes together and prevents centrosome separation. The regulation of the connection and/ or disconnection of two centrosomes is involved in several cellular processes, such as Golgi and cilia positioning (40). On the other hand, CCDC57 is another protein whose functionality has not been well-documented and it may play a role in the centrosome as it has a coiled-coil domain (41).

Interestingly, it was found that Arl4 has two separate promoters in the rat. Jacobs, et al., showed that the mRNA transcription is under the control of the downstream promoter in most tissues while the upstream promoter seems to drive specifically the expression of Arl4 in adult testis (42). In fact, they recorded tissue-specific alternative splicing and promoter use in the Arl4 gene. These findings provide insights into the molecular control of Arl4a protein in spermatogenesis. Apparently, it has several biological functions in different tissues and organelles, and its expression is regulated developmentally.

Broccoli accumulates selenium, consequently reducing the risk of several cancers $(43,44)$; besides, it is required for spermatogenesis and male fertility (45). Selenium significantly increased the Catsper1 and Catsper 2 gene expression in adult male mice (46) and, therefore, it can enhance sperm mobility. The results of our study indicated that Catsper2 was also upregulated with the dose-dependent broccoli extract; however, no significant difference was detected in the Catsper1 mRNA levels. We also observed an obvious increase in spermatogenesis using the extract, which is consistent with the selenium enrichment of broccoli and its positive impact on this process. Our finding is in line with those reported by Raeeszadeha, et al. who observed that the number of spermatogonia, primary spermatocytes, spermatids, and sperm significantly increased with the hydro-alcoholic extract of broccoli $(300 \mathrm{mg} / \mathrm{kg})$ in male mice after 42 days of treatment (32).

As reported in other studies, we found that sperm count, motility, and viability were reduced in Cd-treated mice while the Catsper2 gene was 
down-regulated $(47,48)$. However, our findings diverge from those reported by Mohammadi, et al. who observed a reduction of Catsper1 mRNA level in Cd-treated mice (48). Of course, Catsper1 gene expression is complex, its promoter is bidirectional and regulates the IncRNA (Catsper1au) expression. Indeed, Catsper1au is expressed in adult male mouse testis and can regulate gene expression during spermatogenesis (49). It may be that broccoli contains compounds that bind directly or indirectly to IncRNA regulatory proteins or binds to the Catsper1au target site or some other unknown phenomenon involved in Catsper1 gene regulation.

Previous studies have established that both Sox5 and Sox9 transcription factors interact with the Catsper1 promoter in HEK-293 cells (50). As shown in figure 5, the gene expression in Sox9 was similar to that in the Catsper1 gene, and no differences were observed among treatments in any of them, which agrees with Mata-Rocha, et al.'s findings. However, our findings indicated that Sox 5 gene expression was dramatically reduced in Cd-treated mice as compared with the control. A deeper look revealed that in the 200 and 400 $\mu \mathrm{l}$ extract-treated mice, Sox 5 mRNA level was slightly higher than in the $\mathrm{Cd}$ plus 200 and $400 \mu \mathrm{l}$ extract-treated mice may be due to the other transcription factors or to the miRNA, e.g., miR-195, which targets Sox5 3' UTR and impairs its expression (51).

Quercetin and kaempferol are the predominant flavonoids in commercial broccoli (52). Quercetin attenuates Cd-induced oxidative damage and apoptosis in granulosa cells from chicken ovarian follicles (53). In spite of the antioxidant properties of quercetin, a significant concentration-dependent conflicting effect on sperm viability and motility has already been observed $(54,55)$, which is somewhat in line with our findings. Indeed, we observed that the broccoli diet affected positively the sperm count; however, it negatively impacted sperm viability, though increasing sperm motility slightly (figure 2). Raeeszadeh, et al., determined that the total antioxidant $\mathrm{IC}_{50}$ of broccoli hydro-alcoholic extract is $278 \pm 14 \mu \mathrm{g} / \mathrm{ml}$ (32), a finding that probably explains the negative impact of broccoli extract on sperm viability and highlights the complexity of its antioxidant properties. Additionally, it is reported that the treatment with quercetin markedly inhibited nickel-induced global hypermethylation and DNA hypomethylation of the nuclear factor E2-related factor 2 (Nrf2) promoter (56), which may subsequently affect its downstream target genes. Kaempferol also inhibits DNA methylation by suppressing DNA methyltransferases (57).

It has been previously observed that kaempferol leads to the downregulation of DNMT3 (a kind of DNA methyltransferase) and modulates DNA methylation in cancer (58). Indeed, kaempferol alters 103 DNA methylation positions (hypo-methylation and hyper-methylation) associated with bladder cancer genes (57). Likewise, sulforaphane, another predominant ingredient in broccoli, increased Nrf2 expression, a transcription factor, in prostate tumor cells through epigenetic regulation in mice (59). By the activation of Nrf2/ARE signaling pathways, sulforaphane prevented testicular damage in Cd-treated mice (60). Sulforaphane also reduced Cd-induced toxic effects on human mesenchymal stem cells and showed a significant recovery of cell viability (61). Despite supportive evidence on the impact of sulforaphane as an anticancer agent, the fact is that it also interferes with the T cell-mediated immune response (62) turning it into a double-edged sword.

There is a growing number of reports on the epigenetic regulation of broccoli ingredients and the stable and reversible mechanism regulating 
gene expression. Further research is needed to determine which compounds in broccoli extract stimulate spermatogenesis without a negative effect on sperm viability. Future studies on lower dosage would allow finding a suitable concentration of broccoli to avoid its negative effect on sperm viability and use it as a medicinal plant for male infertility.

In future studies, experiments using real-time PCR would offer a more precise view of gene expression alterations. Probably, Homo sapiens-based protein-protein interaction instead of Mus musculus do not reflect exactly what happens in mice; however, this in silico analysis definitely would be informative as it supports the role of Arl4a in the spermatogenesis process. Our results are promising for the pharmaceutical industry in its efforts to produce medications for infertile men.

\section{Reference:}

1. Kumar N, Singh AK. Trends of male factor infertility, an important cause of infertility: A review of literature. J Human Reprod Sci. 2015;8:191-6. https://doi.org/10.4103/0974-1208.170370

2. Kim DR, Kim HY, Kim HY, Chang MS, Park SK. Trigonellae semen enhances sperm motility and the expression of the cation sperm channel proteins in mouse testes. Evid Based Complementary Altern Med. 2015 ;2015:817324. https://doi.org/10.1155/2015/817324

3. Park WS, Shin DY, Yang WM, Chang MS, Park SK. Korean ginseng induces spermatogenesis in rats through the activation of cAMP-responsive element modulator (CREM). Fertil Steril. 2007;88:1000-2. https://doi.org/10.1016/j.fertnstert.2006.12.014

4. Yang WM, Park SY, Kim HM, Park EH, Park SK, Chang MS. Effects of Panax ginseng on glial cell-derived neurotrophic factor (GDNF) expression and spermatogenesis in rats. Phytother Res. 2011;25:308-11. https://doi.org/10.1002/ptr.3239

5. Awoniyi DO, Aboua YG, Marnewick J, Brooks N. The effects of rooibos (Aspalathus linearis), green tea (Camellia sinensis) and commercial rooibos and green tea supplements on epididymal sperm in oxidative stress-induced rats. Phytother Res. 2012;26:1231-9. https://doi.org/10.1002/ptr.3717

6. Bae WJ, Ha U, Choi JB, Kim KS, Kim SJ, Cho HJ, et al. Protective effect of decursin extracted from Angelica gigas in male infertility via Nrf2/HO-1 signaling pathway. Oxid Med Cell Longev. 2016;2016:5901098. https://doi.org/10.1155/2016/5901098

7. Yari A, Sarveazad A, Asadi E, Raouf Sarshoori J, Babahajian A, Amini N, et al. Efficacy of Crocus sativus $L$. on reduction of cadmium-induced toxicity on spermatogenesis in adult rats. Andrologia. 2016;48:1244-52. https://doi.org/10.1111/and.12568

8. Park EH, Do Rim Kim HY, Park SK, Chang MS. Panax ginseng induces the expression of CatSper genes and sperm hyperactivation. Asian J Androl. 2014;16:845. https://doi.org/10.4103/1008-682X.129129

9. Sun XH, Zhu YY, Wang L, Liu HL, Ling Y, Li ZL, et al. The Catsper channel and its roles in male fertility: A systematic review. Reprod Biol Endocrinol. 2017;15:1-2.

https://doi.org/10.1186/s12958-017-0281-2

10. Kensler TW, Egner PA, Agyeman AS, Visvanathan K, Groopman JD, Chen JG, et al. Keap1-nrf2 signaling: A target for cancer prevention by sulforaphane. Top Curr Chem. 2013; 329:163-77. https://doi.org/10.1007/128 2012339

11. Yang SH, Yu LH, Li L, Guo Y, Zhang Y, Long M, et al. Protective mechanism of sulforaphane on cadmium-induced sertoli cell injury in mice testis via Nrf2/ARE signaling pathway. Molecules. 2018;23:1774. https://doi.org/10.3390/molecules23071774

12. Fahey JW, Wehage SL, Holtzclaw WD, Kensler TW, Egner PA, Shapiro TA, et al. Protection of humans by plant glucosinolates: Efficiency of conversion of glucosinolates to isothiocyanates by the gastrointestinal microflora. Cancer Pre Res. 2012;5:603-11. https://doi.org/10.1158/1940-6207.CAPR-11-0538

13. López-Romero D, Izquierdo-Vega JA, Morales-González JA, Madrigal-Bujaidar E, Chamorro-Cevallos G, Sánchez-Gutiérrez M, et al. Evidence of some natural products with antigenotoxic effects. Part 2: plants, vegetables, and natural resin. Nutrients. 2018;10:1954. https://doi.org/10.3390/nu10121954 
14. Conzatti A, da Silva Fróes FC, Perry ID, de Souza CG. Clinical and molecular evidence of the consumption of broccoli, glucoraphanin and sulforaphane in humans. Nutr Hosp. 2015;31:559-69. https://doi.org/10.3305/nh.2015.31.2.7685

15. Senanayake GV, Banigesh A, Wu L, Lee P, Juurlink BH. The dietary phase 2 protein inducer sulforaphane can normalize the kidney epigenome and improve blood pressure in hypertensive rats. Am J Hypertens. 2012;25:229-35. https://doi.org/10.1038/ajh.2011.200

16. Dinkova-Kostova AT, Kostov RV. Glucosinolates and isothiocyanates in health and disease. Trends Mol Med. 2012;18:337-47. https://doi.org/10.1016/j.molmed.2012.04.003

17. Kerns ML, DePianto D, Dinkova-Kostova AT, Talalay P, Coulombe PA. Reprogramming of keratin biosynthesis by sulforaphane restores skin integrity in epidermolysis bullosa simplex. Proc Natl Acad Sci. 2007;104:14460-5. https://doi.org/10.1073/pnas.0706486104

18. Yanaka A, Fahey JW, Fukumoto A, Nakayama M, Inoue S, Zhang S, et al. Dietary sulforaphane-rich broccoli sprouts reduce colonization and attenuate gastritis in Helicobacter pylori-infected mice and humans. Cancer Pre Res. 2009;2:353-60. https://doi.org/10.1158/1940-6207.CAPR-08-0192

19. Singh K, Connors SL, Macklin EA, Smith KD, Fahey JW, Talalay P, et al. Sulforaphane treatment of autism spectrum disorder (ASD). Proc Natl Acad Sci. 2014;111:15550-5. https://doi.org/10.1073/pnas.1416940111

20. Duruibe JO, Ogwuegbu MO, Egwurugwu JN. Heavy metal pollution and human biotoxic effects. Int J Phys Sci. 2007;2:112-8. https://doi.org/10.5897/IJPS.9000289

21. Mishra S, Bharagava RN, More N, Yadav A, Zainith S, Mani S, et al. Heavy metal contamination: An alarming threat to environment and human health. In: Sobti R, Arora N, Kothari R, editors. Environmental biotechnology: For sustainable future. Singapore: Springer, 2019. p. 103-25. https://doi.org/10.1007/978-981-10-7284-0_5

22. Schürmann A, Koling S, Jacobs S, Saftig P, Krauss S, Wennemuth G, et al. Reduced sperm count and normal fertility in male mice with targeted disruption of the ADP-ribosylation factorlike 4 (Arl4) gene. Mol Cell Biol. 2002;22:2761-8. https://doi.org/10.1128/MCB.22.8.2761-2768.2002

23. Pereira R, Sá R, Barros A, Sousa M. Major regulatory mechanisms involved in sperm motility. Asian J Androl. 2017;19:5. https://doi.org/10.4103/1008-682X.167716

24. She ZY, Yang WX. SOX family transcription factors involved in diverse cellular events during development. Eur J Cell Biol. 2015;94:547-63. https://doi.org/10.1016/j.ejcb.2015.08.002

25. Fahey JW, Zhang Y, Talalay P. Broccoli sprouts: An exceptionally rich source of inducers of enzymes that protect against chemical carcinogens. Proc Natl Acad Sci USA. 1997;94:1036772. https://doi.org/10.1073/pnas.94.19.10367

26. World Health Organization. WHO laboratory manual for the examination and processing of human semen. Fifth edition. Switzerland: WHO Press; 2010. p. 286.

27. Mohammadi S, Movahedin M, Mowla SJ. Up-regulation of CatSper genes family by selenium. Reprod Biol Endocrinol. 2009;7:126. https://doi.org/10.1186/1477-7827-7-126

28. Suzuki N, Mizuniwa C, Ishii K, Nakagawa Y, Tsuji K, Muneta T, et al. Teneurin-4, a transmembrane protein, is a novel regulator that suppresses chondrogenic differentiation. $J$ Orthop Res. 2014;32:915-22. https://doi.org/10.1002/jor.22616

29. Shiota M, Heike T, Haruyama M, Baba S, Tsuchiya A, Fujino H, et al. Isolation and characterization of bone marrow-derived mesenchymal progenitor cells with myogenic and neuronal properties. Exp Cell Res. 2007;313:1008-23. https://doi.org/10.1016/j.yexcr.2006.12.017

30. Zuberi K, Franz M, Rodriguez H, Montojo J, Lopes CT, Bader GD, et al. GeneMANIA prediction server 2013 update. Nucleic acids Res. 2013;41:W115-22. https://doi.org/10.1093/nar/gkt533

31. Khademi N, Raeeszadeh M, Allahveisi A. Effect of different concentrations of hydroalcoholic extract of broccoli on sperm parameters and oxidative stress factors before and after thawing in NMRI mice. J Shahid Sadoughi Univ Med Sci. 2019;26:921-33. http://dx.doi.org/10.18502/ssu.v26i10.482

32. Raeeszadeh M, Khademi N, Akbari A. The effects of broccoli and caraway extracts on serum oxidative markers, testicular structure and function, and sperm quality before and after sperm cryopreservation. Cryobiology. 2021;99:11-9.

https://doi.org/10.1016/j.cryobiol.2021.02.003 
33. Turner LM, Harr B. Genome-wide mapping in a house mouse hybrid zone reveals hybrid sterility loci and Dobzhansky-Muller interactions. eLife. 2014;3:e02504.

https://doi.org/10.7554/eLife.02504

34. Zhou Y, Yang H, Li Y, Lynch B, Jia X. Broccoli seed extract: Genotoxicity and subchronic toxicity studies. Regul Toxicol Pharm. 2015;73:442-51.

https://doi.org/10.1016/j.yrtph.2015.08.003

35. Kim J, Kwon JT, Jeong J, Kim J, Hong SH, Kim J, et al. SPATC $1 \mathrm{~L}$ maintains the integrity of the sperm head-tail junction. EMBO Rep. 2018;19:e45991. https://doi.org/10.15252/embr.201845991

36. Hogarth CA, Calanni S, Jans DA, Loveland KL. Importin $\alpha$ mRNAs have distinct expression profiles during spermatogenesis. Dev Dyn. 2006;235:253-62. https://doi.org/10.1002/dvdy.20569

37. Major AT, Whiley PA, Loveland KL. Expression of nucleocytoplasmic transport machinery: Clues to regulation of spermatogenic development. Biochim Biophys Acta Mol Cell Res. 2011;1813:1668-88. https://doi.org/10.1016/j.bbamcr.2011.03.008

38. Han F, Liu C, Zhang L, Chen M, Zhou Y, Qin Y, et al. Globozoospermia and lack of acrosome formation in GM130-deficient mice. Cell Death Dis. 2018;8:e2532. https://doi.org/10.1038/cddis.2016.414

39. Hou CC, Yang WX. New insights to the ubiquitin-proteasome pathway (UPP) mechanism during spermatogenesis. Mol Biol Rep. 2013;40:3213-30.

https://doi.org/10.1007/s11033-012-2397-y

40. Xia Y, Huang N, Chen Z, Li F, Fan G, Ma D, et al. CCDC102B functions in centrosome linker assembly and centrosome cohesion. J Cell Sci. 2018;131:jcs222901. https://doi.org/10.1242/jcs.222901

41. Nogales-Cadenas R, Abascal F, Díez-Pérez J, Carazo JM, Pascual-Montano A. CentrosomeDB: A human centrosomal proteins database. Nucleic acids Res. 2009;37:D17580. https://doi.org/10.1093/nar/gkn815

42. Jacobs S, Schürmann A, Becker W, Böckers TM, Copeland NG, Jenkins NA, et al. The mouse ADP-ribosylation factor-like 4 gene: Two separate promoters direct specific transcription in tissues and testicular germ cell. Biochem J. 1998;335:259-65. https://doi.org/10.1042/bj3350259

43. Finley JW. Reduction of cancer risk by consumption of selenium-enriched plants: Enrichment of broccoli with selenium increases the anticarcinogenic properties of broccoli. J Med Food. 2003;6:19-26. https://doi.org/10.1089/109662003765184714

44. Finley JW, Sigrid-Keck A, Robbins RJ, Hintze KJ. Selenium enrichment of broccoli: Interactions between selenium and secondary plant compounds. J Nutr. 2005;135:1236-8. https://doi.org/10.1093/jn/135.5.1236

45. Qazi IH, Angel C, Yang H, Zoidis E, Pan B, Wu Z, et al. Role of selenium and selenoproteins in male reproductive function: A review of past and present evidences. Antioxidants. 2019;8:268. https://doi.org/10.3390/antiox8080268

46. Kheradmand N, Kamkar R, Moshajjari M, Baazm M. Effect of selenium and pentoxifylline on expression of CATSPER1 and 2 genes and FSH/LH levels in treated mice by dexamethasone. Andrologia. 2019;51:e13279. https://doi.org/10.1111/and.13279

47. Wang HF, Chang M, Peng TT, Yang Y, Li N, Luo T, et al. Exposure to cadmium impairs sperm functions by reducing CatSper in mice. Cell Physiol Biochem. 2017;42:44-54. https://doi.org/10.1159/000477113

48. Mohammadi S, Gholamin M, Mansouri A, Mahmoodian RS, Babazadeh B, Kebriaei SM, et al. Effect of cadmium and nickel on expression of CatSper 1 and 2 genes in mice. Toxin Rev. 2018;37:216-22. https://doi.org/10.1080/15569543.2017.1350192

49. Jiménez-Badillo SE, Oviedo N, Hernández-Guzmán C, González-Mariscal L, HernándezSánchez J. Catsper1 promoter is bidirectional and regulates the expression of a novel IncRNA. Sci Rep. 2017;7:1-2. https://doi.org/10.1038/s41598-017-13867-2

50. Mata-Rocha M, Hernández-Sánchez J, Guarneros G, de la Chesnaye E, Sánchez-Tusié $\mathrm{AA}$, Treviño CL, et al. The transcription factors Sox5 and Sox9 regulate Catsper1 gene expression. FEBS Lett. 2014;588:3352-60. https://doi.org/10.1016/j.febslet.214.07.024

51. Liu X, Zheng J, Xue Y, Qu C, Chen J, Wang Z, et al. Inhibition of TDP43-mediated SNHG12miR-195-SOX5 feedback loop impeded malignant biological behaviors of glioma cells. Mol Ther Nucleic Acids. 2018;10:142-58. https://doi.org/10.1016/j.omtn.2017.12.001 
52. Koh E, Wimalasiri KM, Chassy AW, Mitchell AE. Content of ascorbic acid, quercetin, kaempferol and total phenolics in commercial broccoli. J Food Compost Anal. 2009;22:63743. https://doi.org/10.1016/.j.jca.2009.01.019

53. Jia Y, Lin J, Mi Y, Zhang C. Quercetin attenuates cadmium-induced oxidative damage and apoptosis in granulosa cells from chicken ovarian follicles. Reprod Toxicol. 2011;31:477-85. https://doi.org/10.1016/j. reprotox.2010.12.057

54. Moretti E, Mazzi L, Terzuoli G, Bonechi C, lacoponi F, Martini S, et al. Effect of quercetin, rutin, naringenin and epicatechin on lipid peroxidation induced in human sperm. Reprod Toxicol. 2012;34:651-7. https://doi.org/10.1016/j.reprotox.2012.10.002

55. Ranawat $P$, Pathak $C M$, Khanduja KL. A new perspective on the quercetin paradox in male reproductive dysfunction. Phytother Res. 2013;27:802-10. https://doi.org/10.1002/ptr.4799

56. Liu CM, Ma JQ, Xie WR, Liu SS, Feng ZJ, Zheng GH, et al. Quercetin protects mouse liver against nickel-induced DNA methylation and inflammation associated with the Nrf2/HO-1 and p38/STAT1/NF-kB pathway. Food Chem Toxicol. 2015;82:19-26. https://doi.org/10.1016/j.fct.2015.05.001

57. Qiu W, Lin J, Zhu Y, Zhang J, Zeng L, Su M, et al. Kaempferol modulates DNA methylation and downregulates DNMT3B in bladder cancer. Cell Physiol Biochem. 2017;41:1325-35. https://doi.org/10.1159/000464435

58. Imran M, Rauf A, Shah ZA, Saeed F, Imran A, Arshad MU, et al. Chemo-preventive and therapeutic effect of the dietary flavonoid kaempferol: A comprehensive review. Phytother Res. 2019;33:263-75. https://doi.org/10.1002/ptr.6227

59. Zhang C, Su ZY, Khor TO, Shu L, Kong AN. Sulforaphane enhances Nrf2 expression in prostate cancer TRAMP C1 cells through epigenetic regulation. Biochem Pharmacol. 2013;85:1398-404. https://doi.org/10.1016/j.bcp.2013.02.010

60. Yang SH, Long M, Yu LH, Li L, Li P, et al. Sulforaphane prevents testicular damage in Kunming mice exposed to cadmium via activation of Nrf2/ARE signaling pathways. Int $\mathrm{J}$ Mol Sci. 2016;17:1703. https://doi.org/10.3390/ijms17101703

61. Alkharashi NA, Periasamy VS, Athinarayanan J, Alshatwi AA. Assessment of sulforaphaneinduced protective mechanisms against cadmium toxicity in human mesenchymal stem cells. Environ Sci Pollut Res. 2018;25:10080-9. https://doi.org/10.1007/s11356-018-1228-7

62. Liang J, Hänsch GM, Hübner K, Samstag Y. Sulforaphane as anticancer agent: A doubleedged sword? Tricky balance between effects on tumor cells and immune cells. Adv Biol Regul. 2019;71:79-87. https://doi.org/10.1016/j.jbior.2018.11.006 